\title{
A Review of Drought Indices
}

\author{
Saeid Eslamian ${ }^{1}$, Kaveh Ostad-Ali-Askari ${ }^{2 *}$, Vijay P. Singh ${ }^{3}$, Nicolas R. Dalezios ${ }^{4}$, \\ Mohsen Ghane $^{5}$, Yohannes Yihdego ${ }^{6}$, Mohammed Matouq ${ }^{7}$ \\ ${ }^{I}$ Department of Water Engineering, Isfahan University of Technology, Isfahan, Iran \\ ${ }^{2 *}$ Department of Civil Engineering, Isfahan (Khorasgan) Branch, Islamic Azad University, Isfahan, Iran \\ ${ }^{3}$ Department of Biological and Agricultural Engineering \& Zachry Department of Civil Engineering, Texas A \\ and M University, 321 Scoates Hall, 2117 TAMU, College Station, Texas 77843-2117, U.S.A. \\ ${ }^{4}$ Laboratory of Hydrology, Department of Civil Engineering, University of Thessaly, Volos, Greece \& \\ Department of Natural Resources Development and Agricultural Engineering, Agricultural University of \\ Athens, Athens, Greece. \\ ${ }^{5}$ Department of Civil Engineering, South Tehran Branch, Islamic Azad University, Tehran, Iran \\ ${ }^{6}$ Snowy Mountains Engineering Corporation (SMEC), Sydney, New South Wales 2060, Australia. Geo \\ Information Science and Earth Observation (ITC), University of Twente, the Netherlands \\ ${ }^{7}$ Al-Balqa Applied University, Chemical Engineering Department, President of Jordan Japan Academic Society, \\ JJAS. P.O. Box 4486, Amman 11131- Jordan.
}

*Corresponding Author: Dr. Kaveh Ostad-Ali-Askari, Department of Civil Engineering, Isfahan (Khorasgan) Branch, Islamic Azad University, Isfahan,Iran.Emails: Koa.askari@khuisf.ac.ir, Kaveh.oaa2000@gmail.com

\begin{abstract}
Shortage of food and water resources resulted from climatic crises has alarmed people around the world, in particular that the rain-watered agriculture and vegetation of natural resources suffer from the irregular rainfall in most of the water years. Drought and wetness year causes significant impacts on water resources, crops, commerce, trade and in general, economy and political crises. Give the fact that some countries like Iran are located in the dry belt of the world their rainfall pattern possess unique features: low intensity and high fluctuation. The persistent negative fluctuations of precipitation lead to drought characterized by different severity which imposes extensive damage on ecological and economic condition of the affected areas. Therefore, in this paper the comprehensive review of drought indices is presented and the advantages and disadvantages related to each index is discussed enabling policy makers to manage drought effectively.
\end{abstract}

Keywords: Drought, Precipitation, Ecological, Rainfall

\section{INTRODUCTION}

Drought is a natural disaster that has considerable impacts on agriculture and economy and thus affecting lives of the population in drought-stricken area. Despite earthquake and flood, drought has seemingly limited mortality but affects greater regions and it extends more period of time (30).

Palmer was a pioneer who defined the drought as consequence of permanent precipitation shortage against to the mean normal conditions in long term [3].

Herbst et al (1966) developed a method to assess meteorological drought that were modified later for arid regions by Mohan \& Rangacharya (1991). The modified approach is based on the fact that monthly precipitation is investigated by 4 variables i.e. onset and termination of drought, severity and duration. If drought is occurred in a particular month, it is investigated whether in the next month the drought is continued or terminated. This approach is iterated until end of drought is announced [8].

Yazdani et al (2007) examined the drought in Zayanderud watershed and the lands in neighborhood during a 32-years period, moreover, they studied precipitation statistics in 85 rain gauge stations using percent of normal (PN) index, dispersion of precipitation index (DPI) and standardized precipitation index (SPI). Firstly, they determined the value of drought using the three mentioned indices and then classified the drought in terms of affected area percent.

In another research, Lukas et al (2003) calculated and compared three drought indices in Greece using data collected from 28 stations during 40 years (1960-2000). The indices used in their research 
include standardized precipitation index (SPI), rainfall abnormality index (RAI) and Z index. At first they calculated the value of indices for 3,6,12 and 24-month interval and then compared them together. The results indicated that all three indices had similar efficiency in determination of severity and persistence of the drought [1-23].

Hong et al (2004) developed a model to evaluate severity of drought risk in two crops - maize and soy - in Nebraska, US. As the final effects of drought phenomenon in agriculture is on crops and fruits, the purpose of this study is to present a simple effective definition for agricultural drought based on yield performance and to propose a new index to evaluate the severity of agricultural drought considering all effective factors as well [22].

Lukas et al (2008) in a paper titled 'climate changes on drought severity' evaluated effects of climate changes on drought severity in wide region of Tesla in Greece. For evaluation, they used the data collected from 50 stations during 30 years. Using the SPI, they concluded that drought had occurred with different severity in all parts of this region in different intervals [24-26].

According to the findings of Raziei et al (2007) obtained by SPI in Sistan and Balouchestan province, Iran, probability of drought persistence in central areas is more than 70 percent while in eastern areas is less than 50 percent. Furthermore, the central part of this province is located in drought approximately in 30 percent of the year. Therefore, this province has more vulnerable situation compared to other investigated provinces in this paper [27-34].

In Netherlands, the difference between rainfall and evaporation in the mid summer of the year has repeatedly been used to evaluate severity of drought in the same year. This method is strongly related to moisture deficit for plants during the growing season. Precipitation deficit in every period is defined as the difference between precipitation and evapotranspiration in that period. Evapotranspiration is defined as evaporation of the reference plant. In general, plants don't grow effectively in the periods with moisture deficit. In the absence of moisture deficit, the precipitation surplus will be discharged in runoff. Without conservation measures, these water surplus can't compensate evaporation deficit in future [11].

Hassanzade (2009) presented four new drought indices (MPD, RCPD, RMPD, CPD) to investigate drought situation in Isfahan using statistics of all synoptic stations of the province having more than 10 year statistics. He, also, prepared maps of drought severity for Isfahan and concluded that these new indices would perform more precisely and better than SPI and had been effective in drought assessments. These indices revealed the droughts occurred during 1999 to 2001 accurately, whereas SPI failed to do so in most of the stations [2].

Ghasemi (1997) calculated hydrological and meteorological drought indices in Karkheh basin using statistics of 12 rain gauge and hydrometric stations in this region, these indices include: SPI, deciles, Q95, Q7.10, Q7.20, Q30.10 and Q4.3, he then compared these indices. Finally, he performed drought zoning using GIS and concluded that hydrological and meteorological drought had not occurred simultaneously in any stations and in 50\% of the time, in average, the drought periods were occurred simultaneously. Furthermore, other conclusions of this study are as follow: meteorological drought periods were longer than hydrological ones; the drought in west of basin was severe than the east part; drought severity and drought frequency had direct relationship [6].

Again, Hassanzade et al (2011) in a study titled 'Application of linear momentum method to evaluate drought indices Cumulative Precipitation Deficit (DPD) and Maximum Precipitation Deficit (MPD) based on regional frequency' evaluated these indices using statistics of 11 synoptic stations in Isfahan province as a semi-arid region. In their study, Generalized Logistic Distribution was selected as the best regional distribution method to analyze both indices. Moreover, the drought severity with different return periods was determined and the results showed that Naeen, Ardestan and east Isfahan stations had suffered the most severe drought in the province. At the end, the required agricultural water to pass drought periods was calculated for this province [17].

Eslamian et al (2012) in a paper called 'Application of linear momentum method to analyze regional frequency of monthly drought indices' performed regional frequency analysis of CPD and MPD using statistics of 11 synoptic stations in Isfahan province as a semi-arid region. The results suggest that during May to October the region is homogenous and for the remaining time, the region is divided to 2 smaller homogenous parts applying classification and division techniques. Moreover, in this study the drought severity with different return periods was calculated. The results indicate that in all 
stations, the most severe drought has occurred during June to August - that is from end of spring to the midsummer- and in the Ardestan, Naeen, Khour \& Biabanak stations it was more severe than other stations. Using the results of this study, it is possible to estimate the required water for agriculture in each month and then manage the available water in this province effectively [13].

\section{DROUGHT CONCEPT}

Drought, in general, implies deficiency of rainfall of such magnitude which would negatively affect a given region [40]. However, it is difficult to make a relationship between definition of drought and hydrological phenomena because, firstly, it may not affect all components of hydrologic system simultaneously, and secondly, drought is not an absolute phenomenon, rather it is relative deficiency of moisture. By this definition, the high demand for water may lead to drought takes place, while the rainfall is in normal range [35-57]. On the other hand, this definition is general and has not distinguished between important aspects of the drought including meteorological, hydrological, agricultural and socio-economic drought [11].

Many definitions have been proposed for drought so far, but each one is presented from a specific point of view. Overall, the concept of drought has long suffered from a comprehensive definition encompassing all different aspects and so this phenomenon has not yet been understood adequately. Since all aspects of life and different parts of the society, particularly the natural environment, are influenced by drought directly or indirectly, the understanding of this concept can help practitioners and policymakers manage the different parts of the economy effectively.

The reasonable definition for drought which is accepted more than other definitions is that 'drought is resulted from a period of abnormal arid conditions that are lasted sufficiently to cause non - balance in hydrological situation of a region'. In last decades, among the natural disasters affected population communities, the frequency of drought phenomenon in terms of severity, duration, affected area, mortality, loss of property and social impacts in long term, has been more than other natural disasters. Moreover, this phenomenon differs from other natural disasters, in a way that it occurs slowly over a relative long period of time and its effects often build up with more delay than other natural hazards [58-73].

\section{TYPES OF DROUGHT}

In this paper, four types of drought according to the Wilhite \& Glantz (1985) classification are presented:

\subsection{Meteorological Drought}

In meteorological view, drought occurs when precipitation is less than normal and is characterized by change of weather patterns. Therefore, drought is essentially referred to dryness resulted from precipitation deficit. Climatologically, when precipitation in a region in a given period of time is less than average precipitation in that region in the same period, the drought is occurred in that region because the creatures (plants, animals, humans) have been compatible with average precipitation received in that region and in case of precipitation shortfall, their lives will be exposed to threat [4].

Another definition for Meteorological drought involves precipitation shortfall or any change in intensity and velocity of the rain that results in decreased cloudiness and relative humidity as well as increased temperature, evapotranspiration, radiation and hurricanes [18].

The definition of meteorological drought varies in different countries and in different periods of time and thus applying a definition which is common in a region could be inappropriate in other parts of the world. The importance of meteorological view is resulted from the fact that meteorological parameters could be the first indicators of drought occurrence [18].

\subsection{Hydrological Drought}

In hydrological view the drought occurs when level of surface water and groundwater table is less than the long-term average. In this view, the drought indicators include level of streams, lakes and groundwater. The climate fluctuations serve as the main factor to determine severity of this drought which themselves have physical and natural basis. Moreover, human activities such as land use changing, land degradation and dam constructions have impacts on basin characteristics as well as occurrence and severity of hydrological drought. Today, due to extensive urbanization, industrialization and water shortage, this type of drought becomes a complex problem.

Farmer \& Wigley stated that 'hydrological drought occurs when water resources used for industry, for human or animal consumption, or to support agriculture reach low levels' [27]. 
Furthermore, there is a delayed time between precipitation shortfall and water resources reduction and thus indicator of hydrological drought cannot be regarded as onset of meteorological drought.

\subsection{Agricultural Drought}

It happens when soil moisture is less than plant's demand for water. As result, the plant experiences the tension and the yield is decreased. Because different plants have different demands for water, therefore, this concept varies in each plant. Agricultural drought is resulted from precipitation shortfall, increased temperature and wind in which volume and temporal dispersion of the precipitation serve as the most significant factor. Normally, this type of drought is occurred after meteorological drought and before hydrologic drought [38].

\subsection{Socio-Economic Drought}

It happens when water resources needed for industrial, agricultural and household consumption is less than what is needed and so this situation results in socio-economic anomalies. This drought is consequence of complex environmental processes which affects human communities. Given the occurrence of water crisis and crops deficit, it is not strange that lives of people to be negatively influenced by the drought and consequently the negative impacts of drought would appear in the society. Poverty, unemployment, outbreak a disease and insecurity are consequences of this type of drought that affects economic activities of people in a community such as impacts on revenue from sales, and happens when supply of an economic good (water, food, fodder, ...) is less than demand (needed quantity).

Socioeconomic drought depends on spatial - temporal processes in supply and demand and occurs when demand for an economic good exceeds supply as result of a weather-related deficit in water supply. Supply of some goods like water, grains, fish and hydro-electric energy depends on weather conditions. Socioeconomic definitions of drought associate the supply and demand of some economic good with elements of meteorological, hydrological, and agricultural drought.

Some researchers add another category to this classification called edaphic drought. This type of drought is defined by limited soil penetration focusing on qualities. Edaphic drought will render the soils more vulnerable to aeolian erosion; as result, the vegetation will suffer from moisture deficit, the nutrients in surface of soil will decreased and the plant will have dried out [27].

As it was said, the drought starts initially as result of precipitation shortfall compared to normal conditions as meteorological drought, consequently, the moisture content in the soil will be decreased and the agricultural drought is occurred. As result of precipitation shortfall, the water resources are degraded and hence the hydrological drought happens. Finally, the socioeconomic drought happens due to anomalies resulted from water shortage [20].

\section{How to STUdy DROUGhT}

With regard to research activities of different authors in different disciplines, the specific definitions are presented for drought that finally has led to classification of this phenomenon. It caused to invent specific methodologies focusing on prominent indicators such as precipitation, stream flows, soil moisture, underground reservoirs, economic damages etc [33]. In the following, some of these methods to study the drought are discussed.

\subsection{Water Balance Method}

As one of the most effective factors on drought is content of moisture in the soil, this issue has accounted for part of the drought studies. Considering the effect of this factor on plants' growth and any biological action, it is classified as agricultural drought in which the variation of soil moisture during the periods when the plant needs water is taken into account.

Most indicators used for this type of drought try to indentify and explain the soil's water balance. In general, there are numerous methods to calculate water balance that often involve potential evapotranspiration. Two common indicators in this context that have been used by authors are: Thorn Thwaite index and Palmer index.

\subsection{Synoptic Analysis Methods}

Study of drought phenomenon as a dynamic climatic process has not attracted the researchers' attention. In this case, Tanhehill, studied the rainfall distribution in the United States setting the 
Atlantic high-pressure systems as reference. He believes that this factor controls the degree of precipitation in the US. In another study, Bond used the general qualities of regional circulation as reference to analyze drought in North America. He found out that anti-cyclonic circulations in moderate regions of the north hemisphere had direct effects on current of air and occurrence of drought [18].

\subsection{Precipitation Data Analysis Method}

It is a common method to analyze the drought because all types of precipitation data are available for different parts of the globe. In fact, precipitation is the most important variable whose variations are reflected directly in soil moisture, stream flows and underground reservoirs and thus it is the first element paid attention to in study of drought.

Numerous indices have developed for study of the drought from this viewpoint. The simplest one is prolonged precipitation average as a threshold by which values of precipitation during studied periods are analyzed and evaluated. Calculation of precipitation percentage relative to prolonged precipitation average can serve as another index and its threshold may take different values.

Standardized precipitation index (SPI) is included in this category and is introduced in section of drought indices.

\subsection{Stream Flow Analysis Methods}

This type of analysis which generally deals with stream flows, water reservoirs, lakes and underground tables are known to hydrological drought and studied by data associated with quantity of stream flows.

Prior to analysis of any hydrological series such as maximum, minimum or average of annual current, it is necessary to investigate the data quality and apply all available information. If for whatever reason, the series suffer deficit, the lost data should be retrieved.

\subsection{Method of using Historical and Geomorphologic Data}

Historical information obtained from memories, family traditions of the residents and geomorphologic phenomena of the old environments, narrates the occurrence of natural disaster like drought in the past. The memories such as severe reduction of the crops or precipitation shortfall in the past years keep in the minds due to their impacts on communities, but unfortunately most of the time they have not archived in written form.

Travelogue of tourists, early discoverers and migrants may contain important information. Another instrument to study the drought in the distant past is archaeologists' investigations. Having gathered evidences and relevant documents, the important issue is how to associate them with drought problems. Normally, finding the functions relating values of agricultural damages and social impacts to annual precipitation and stream flows during the drought period is a challenging work [2].

\section{DROUGHT INDICES}

According to the indicators of the given drought, severity and duration of the drought is represented by an index. An index assimilates different meteorological and hydrological parameters including precipitation, temperature, evapotranspiration, runoff and other water supply indicators into a single numerical value or formula and gives a comprehensive picture of decision making. Such an index is more readily useable and comprehensible than raw data and it is usually presented as a numerical value in order to create decision making power for planners and policy makers. The authorities or public and private committees take actions to evaluate drought and react to it using these indices.

World meteorological organization in 1992 defined the drought index as 'an index which is related to some of the cumulative effects of a prolonged and abnormal moisture deficiency'. Friedman identified four basic criteria that any drought index should meet [14]:

1. The timescale (period) should be appropriate to the problem at hand (drought).

2. The index should be a quantitative measure of large-scale, long-continuing drought conditions

3. The index should be applicable to the problem being studied.

4. Long accurate past record of the index should be available or computable. 
Numerous indices have been developed for drought representation, while no one has inherent priority over others some of them have better performance in specific conditions. For example, Palmer drought index is extensively used in the United States and Australia. This index yields better results in vast plains with uniform roughness than mountainous terrains, whereas for mountainous terrains the surface water supply index (SWSI) is better representative of the drought. Among the different drought indices, the Palmer drought severity index (PDSI), Crop specific drought index (CSDI), Surface water supply index (SWSI) and Standardized precipitation index (SPI) are extensively used for water resources management, monitoring and prediction of agricultural drought. Many designers of water projects suggest that the status of drought should be investigated through multiple indices and the decisions are not made based on a single index only.

Here, the above indices together with other meteorological and hydrologic index are presented.

\subsection{Palmer Drought Severity Index (PDSI)}

It was developed by Palmer in 1965. PDSI bases its concept of drought on temperature, precipitation and soil moisture. This index is used in monthly timescale and to compute PDSI, four major factors are needed through complex formulation: precipitation, temperature, soil moisture and evapotranspiration.

PDSI is a moisture algorithm for soil that is computed for relatively homogenous regions. It is one of the most sophisticated and accurate warning systems of drought. PDSI is the first comprehensive drought index and an effective method to determine long term drought (monthly scale), however it is not suitable for characterization of short term drought (weekly scale) [18]. Table 1 presents the different classes based on Palmer index. The supposed precipitation in this index is amount of rainfall in a given month that will maintain evapotranspiration, run off and moisture content for considered climate at normal level.

Table1. Palmer drought index categories (18)

\begin{tabular}{|l|l|}
\hline Category & Index value \\
\hline Extremely wet & 4 and more than 4 \\
\hline Very wet & 3 to $3 / 99$ \\
\hline Moderately wet & 2 to $2 / 99$ \\
\hline Slightly wet & 1 to $1 / 99$ \\
\hline Incipient wet spell & 0.5 to 0.99 \\
\hline Near normal & -0.49 to $0 / 49$ \\
\hline Incipient drought & -0.5 to $-0 / 99$ \\
\hline Mild drought & -1 to $-1 / 99$ \\
\hline Moderate drought & -2 to $-2 / 99$ \\
\hline Severe drought & -3 to $-3 / 99$ \\
\hline Extreme drought & -4 and less than -4 \\
\hline
\end{tabular}

For a specific month, the difference between supposed precipitation and actual rainfall is (d). When this value is multiplied by $(\mathrm{k})$ distribution factor (obtained experimentally), the deviation moisture $(\mathrm{Z}=\mathrm{kd})$ is given where $\mathrm{Z}$ is function of time and place. This index depends on $\mathrm{Z}$ and given by (24):

$$
X_{i}=0.897 X_{i-1}+\frac{Z_{i}}{3}
$$

In 1984 Alley discussed two advantages of Palmer index caused its popularity:

1. PDSI improves the planners' decision making power with respect to evaluation and measurement of climatic anomalies in a region.

2. PDSI gives a spatial and temporal picture from historical droughts.

However, this index has considerable limitations. These limitations expressed by Alley in 1984 and Karl \& Knight in 1985 include:

1. Arbitrary selection of quantitative values for intensity of drought and beginning and ending a drought or wetness based on Palmer's study on central Iowa and western Kansas that are not accepted scientifically. 
2. PDSI is sensitive to moisture conditions and type of soil and thus applying this index for climatic planners may be so simple and commonplace.

3. This index excludes snowfall, snow-pack and frozen ground and all precipitation is included as rainfall. Therefore, it is not applicable for regions with snowfall periods in a year.

4. The natural lag between rainfall and run off is neglected. Moreover, no run off is considered to be replaced in model in order to determine water capacity of surface soil and subsurface layers.

5. PDSI uses the Thornthwaite method to estimate potential evapotranspiration. Although this index has had wide acceptance, it is still considered an approximation.

\subsection{Surface Water Supply Index (SWSI)}

Developed in 1982 by Shafer \& Dezman, SWSI is similar to Palmer index however it incorporates snow hydrology in index. It is used in monthly timescale and the primary elements include rainfall and snow [32].

SWSI developed for Colorado to complement PDSI because this region is characterized by heavy snowpack and it is considered as main element in surface water supply. Therefore, SWSI is estimated for the considered basin addressing snowfall, streamflow, rainfall and reservoir storage [18].

Essentially, Palmer index is a modified algorithm for soil moisture in relatively homogenous regions and it is not designed for the surfaces with high topographic diversity. Furthermore, PDSI has not taken the run-off as result of snowfall into account. Therefore, Shafer and Dezman developed SWSI as representative of surface water status and explained it as mountain-related index in mountainous terrains characterized by snowfall as primary source of water storage [18].

The aim was to add climatic and hydrologic features in index and turn it to an index by similar values to Palmer index for the important rivers in Colorado basin. The values were standardized comparing the basins [38].

Four primary inputs for this index include: snowpack, stream flows, rainfall and other resources for water storage. During summer months, the snowpack is replaced by stream flows that is a usual limitation of this index [18].

SWSI is defined as follow [38]:

$$
S W S I=\frac{a P_{\text {snow }}+b P_{\text {prec }}+c P_{\text {strm }}+d P_{\text {resv }}-50}{12}
$$

Where,

$\mathrm{P}_{\text {snow: }}$ probability of non-exceedance related to snow

$\mathrm{P}_{\text {prec: }}$ probability of non-exceedance related to precipitation.

$\mathrm{P}_{\text {strm: }}$ : probability of non-exceedance related to stream flows

$\mathrm{P}_{\text {resv }}$ : probability of non-exceedance related to reservoirs storage

a, b, c, d: weights for each component.

Percent of normal precipitation index (PNPI)

This index developed in 1994 by Wileke and his colleagues and bases its concept on dividing the actual precipitation by normal. The only factor needed to PNPI calculation is precipitation and it is used in monthly timescale [18].

PNPI is favorable for communicating drought levels to the public and due to its simplicity in measuring precipitation in a region is the best and most effective index used in Iran for drought characterization.

This index yields the best results when it is used for a single region or a single season. However, it should be noted that PNPI can be misleading and presents different conditions dependent on the region and season.

This index is calculated by dividing actual precipitation by normal precipitation multiplied by 100 and often is used in monthly timescale, for example from one to several months that represents a given season. It is given as: 
$P N I=\frac{P_{i}}{P} \times 100$

Where,

PNI: precipitation normal index

$\mathrm{P}_{\mathrm{i}}$ : actual precipitation

P: normal precipitation

This index is applicable when average of precipitation is overlapped with mean or when the precipitation distribution is normal. As the seasonal and monthly precipitations lack this feature, it is regarded as a limitation for this index.

Table2. PNPI categories

\begin{tabular}{|l|l|}
\hline Category & Index (percent) \\
\hline Normal & More than 80 \\
\hline Weak drought & 70 to 80 \\
\hline Moderate drought & 50 to 70 \\
\hline Severe drought & 40 to 50 \\
\hline Extreme drought & Less than 40 \\
\hline
\end{tabular}

\subsection{Crop Moisture Index (CMI)}

It was developed by Palmer in 1968. This index is based on weekly mean temperature and precipitation in a region relative to CMI obtained for previous week and has weighted coefficients in time and space [38].

This index is driven from meteorological approach to show general conditions for planting crops in every week. This method was developed by Palmer in the same way as PDSI. While PDSI was used to show drought and wetness, CMI was designed to evaluate short term moisture conditions in the primary regions of producing agricultural crops. This index reacts instantly to climate changes. It is evaluated with respect to the time and space. Therefore, the maps which illustrate weekly CMI in the US can be used to compare the moisture conditions in different regions [38].

As CMI is designed to show effective moisture conditions on growing crops in short term, then it is not a good instrument to show long term drought. On one hand, due to sensitivity of this index to short term changes in precipitation and temperature, it may result in misleading information about long term conditions. For example, an effective precipitation during the drought may take into account CMI values to show the moisture conditions while the drought is continued in that region. This limitation prevents using CMI to show moisture conditions outside seasonal growth, particularly in those droughts which are persistent for several years. On the other hand, this index predicts potential drought [18].

\subsection{Crop Specific Drought Index (CSDI)}

It was developed by Meyer and his colleagues in 1993 and modified in 1995 by Meyer and Hubbard. This index was developed after CMI. It bases its concept on calculated sum of evapotranspiration and dividing it by the evapotranspiration may have been occurred during growth period of a specific crop. The most important climatic factor used in this index is evapotranspiration. This index is used in seasonal time scale [28-29].

\subsection{Soil Moisture Drought Index (SMDI)}

SMDI was presented by Hollinyer and colleagues in 1993 and depends on daily sum of soil moisture for one year. The only climatic factor used in this index is moisture of soil. It is used in annual time scale [21].

\subsection{National Rainfall Index (RI)}

It was introduced by Gommes and Petrassi in 1994. Its concept is based on patterns and abnormalities of precipitation on continental scale and the only factor used in it is precipitation. This index is used in two-time scale of year and century [16]. 


\subsection{Rainfall Anomaly Index (RAI)}

It was introduced by Van-Rooy in 1965 and is based on calculated precipitation against random values from -3 to +3 ; as the irregularities of precipitation assigned 10 bounds. The only effective factor in this index is precipitation. It is applied in both monthly and annual time scale as well [35].

The steps to calculate rainfall anomaly index (RAI) is as follow:

1. Calculate the long term average of monthly precipitation $(\bar{P})$ in given station.

2. Extract the mean of 10 values of the maximum precipitation occurred in statistical period $(\bar{m})$.

3. Extract the mean of 10 values of the minimum precipitation occurred in statistical period $(\bar{X})$

4. Compare the monthly precipitation data (P) to long term mean, if $P>\bar{P}$, then, RAI is given by following equations:

$$
R A I=3\left[\frac{P-\bar{P}}{\bar{m}-\bar{P}}\right]
$$

And if $P<\bar{P}$, then $\mathrm{RAI}$ is given by:

$$
R A I=-3\left[\frac{P-\bar{P}}{\bar{X}-\bar{P}}\right]
$$

In the former the abnormality is positive and in the latter is negative.

5. Assign +3 and -3 thresholds to the means of 10 maximum positive abnormalities and 10 minimum negative abnormalities, respectively.

Table 3 presents classification of drought severity in terms of rainfall anomaly index.

Table3. Classification of drought severity by RAI

\begin{tabular}{|l|l|}
\hline Category & Assigned threshold to RAI \\
\hline Normal & $0 / 3$ to 3 \\
\hline Weak drought & $-1 / 2$ to $0 / 3$ \\
\hline Moderate drought & $-1 / 5$ to $-1 / 2$ \\
\hline Severe drought & -3 to $-1 / 5$ \\
\hline Extreme drought & Less than -3 \\
\hline
\end{tabular}

\subsection{Reclamation Drought Index (RDI)}

It is similar to SWSI and is calculated based on climatic and meteorological factors, level of river water, snowfall, stream flows, reservoirs level and temperature; it is used in monthly time scale. RDI has recently developed as an instrument to determine severity and duration of drought and to predict the onset and end of the drought period. The motive to develop this index in the United States was emergency relief funds given to the states affected by the drought. The index allowed the affected states to seek assistance in the form of financial aid from the federal government for purpose of mitigating the effects of drought. Table 4 presents classification of drought severity in terms of RDI [36].

Table4. Classification of Reclamation drought index

\begin{tabular}{|l|l|}
\hline Category & RDI value \\
\hline Very wet & 4 or more than 4 \\
\hline Moderately wet & $1 / 5$ to 4 \\
\hline Normal to mild wet & 1 to $1 / 5$ \\
\hline Normal to mild drought & 0 to $1 / 5$ \\
\hline Moderate drought & -4 to $-1 / 5$ \\
\hline Severe drought & -4 or less than -4 \\
\hline
\end{tabular}


Reclamation drought index is calculated at the river basin level and includes water storage components like precipitation, snowpack, stream flows and reservoirs level. It is different from Palmer drought severity index in a way that it depends on the temperature. RDI is applicable for all regions enabling takes to account both water storage and climatic factors components.

\subsection{Effective Precipitation Index (EPI)}

This index developed by Byun and Wilhite in 1999 is based on quantitative analysis of daily effective precipitation. Therefore, its most effective factor is precipitation and is used in daily time scale. Table 5 presents drought classification with respect to this index [12].

Table5. EPI classification (12)

\begin{tabular}{|l|l|}
\hline Category & Values \\
\hline Normal & More than -7 \\
\hline Moderate drought & $-0 / 7$ to $-1 / 5$ \\
\hline Severe drought & $-1 / 5$ to $-2 / 5$ \\
\hline Extreme drought & Less than $-2 / 5$ \\
\hline
\end{tabular}

EPI is the recent drought index applying in characterization of both hydrological and meteorological droughts. Hence, using this method, it is possible to investigate status of drought for any period considering the definition of drought in that area and prove the drought occurrence in soil and water resources. It is given by the following relation:

$$
E P I_{i+j-1}=\frac{A_{i+j-1}-M_{i+j-1}}{S D_{i+j-1}}
$$

Where,

$\mathrm{EPI}_{\mathrm{i}+\mathrm{j}-1:}$ effective precipitation index during actual cumulative period

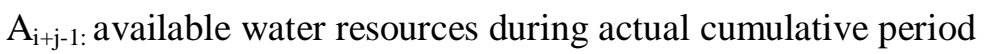

$\mathrm{M}_{\mathrm{i}+\mathrm{j}-1:}$ mean available water resources in a specific day within year

$\mathrm{SD}_{\mathrm{i}+\mathrm{j}-1}$ : standard deviation of available water resources in a specific day within year.

$\mathrm{i}+\mathrm{j}-1$ : actual cumulative period where $\mathrm{i}$ is hypothesized cumulative period (365-day period) and $\mathrm{j}$ is dry or wet period.

\subsection{Bhalme And Mooley Drought Index (BMDI)}

It was invented by Bhalem and Mooley in 1980. It considers the percent departure of monthly or annual precipitation from its normal mean. This index is similar to Palmer index and is a recurrent one, that is, it takes into account influence of precipitation from the previous month [31].

Table6. Drought status based on Bhalme and Mooley drought index (BMDI)

\begin{tabular}{|l|l|}
\hline Weather feature & Domain \\
\hline Near to normal & $-0 / 99$ to $0 / 99$ \\
\hline Weak drought & -1 to $-1 / 99$ \\
\hline Moderate drought & -2 to $-2 / 99$ \\
\hline Severe drought & Less than or equal -3 \\
\hline
\end{tabular}

Table 6 presents different categories in Bhalme and Mooley drought index (BMDI). The steps to calculate this index is as follow:

1. Calculate long term mean $(\bar{X})$ and standard deviation (S) of monthly precipitation data during evaluation period in considered stations,

2. Calculate monthly moisture index (MI), i.e. percent departure of monthly precipitation from its long term mean.

3. Determine the minimum values for monthly moisture during the studied period and estimate their cumulative values.

4. Fit the linear regression on the least value of monthly cumulative moisture using least squares technique [10]. 


\subsection{Standardized Precipitation Index (SPI)}

McKee et al developed SPI in 1993. This index is obtained by difference of precipitation from the mean for a given time scale and then dividing it by standard deviation. It relies only on precipitation data and is computed for 3, 6, 12, 24 and 48 month periods.

SPI is an analytical tool for precipitation data. It aims to assign numerical values to precipitation so that comparison of various regions with highly different climates becomes possible. SPI compares the cumulative precipitation of a given station or region in a specific interval (for example past 3 months or past 6 months) to average of precipitation in the same interval during all statistical period.

Conceptually, SPI indicates the standard deviation above or below the average record.

SPI is used for different time scales based on probability of precipitation. Moreover, it predicts drought before occurrence and helps estimating severity of the drought, this index is computationally less sophisticated than Palmer index as well. Today, planners and decision makers dealing with drought know that SPI is a multipurpose index and understand its particular importance. Besides, they are aware that the values of input data in SPI could be changed and describe this as limitation of this index [19].

Calculation of SPI for each region is performed based on the recorded precipitation data in long term for a given period. The long term precipitation reports have been fitted with a probability distribution; therefore, the mean standardized precipitation for each region in any given period is set to zero and the standard deviation is 1 [29].

Furthermore, McKee et al in 1993 defined criteria for occurrence of drought in different time scales based on SPI scores. As they argued, if negative score of SPI is consistently observed a drought is said to have occurred, and if it reaches the value of -1 or less the drought is considered severe; accordingly, the positive sign of SPI scores means end of drought event. Therefore, any drought event has a period characterized by its start, end and severity in a given month [19].

They expressed severity of drought based on SPI as [29]:

$S=\sum_{i=1}^{D} S P I_{i}$

Where,

$\mathrm{S}$ denotes severity of drought, $\mathrm{SPI}_{\mathrm{i}}$ is score of SPI during drought periods (less than -1), and D is number of drought periods.

Using an analysis in vicinity of Colorado stations, McKee argued that in mild drought the score of SPI was $24 \%$, in moderate drought $9.2 \%$, in severe drought $4.4 \%$ and in extreme drought it was $2.3 \%$ [29].

Table7. Classification of drought and wetness using SPI

\begin{tabular}{|l|l|}
\hline Category & SPI \\
\hline Extremely wet & +2 and more than +2 \\
\hline Very wet & $1 / 5$ to $1 / 99$ \\
\hline Moderately wet & 1 to $1 / 49$ \\
\hline Near to normal & 0.99 to $-0 / 99$ \\
\hline Moderate drought & $-1 / 49$ to -1 \\
\hline Severe drought & $-1 / 99$ to $-1 / 5$ \\
\hline Extreme drought & -2 and less than -2 \\
\hline
\end{tabular}

\section{DECILES}

It was developed by Gibbs and Maher in 1967. This index is obtained by dividing the distribution of long term record precipitation into $10 \%$ parts and each part is called a decile. The first decile represents the precipitation value not exceeded by the lowest $10 \%$ of all precipitation and the second decile represents the precipitation value not exceeded by the lowest $20 \%$ of precipitation [15].

The only effective factor in computing this index is precipitation and the time scale used is monthly. This method was introduced in response to deficits in percent of normal index. Deciles index has been selected as a meteorological index for monitoring the drought by Australian Drought Watch System 
due to its simple computations and requiring the less data than Palmer index. To compute the deciles, the extended length of climatic data is needed and it is disadvantage of this method. Table 8 represents the classification of drought based in this index [18].

Table8. Classification of drought based on deciles method

\begin{tabular}{|l|l|l|}
\hline Deciles & Percent & Category \\
\hline $1-2$ & The lowest 20\% & Much below normal \\
\hline $3-4$ & Next the lowest 20\% & Below normal \\
\hline $5-6$ & Mid 20\% & Near to normal \\
\hline $7-8$ & Next the highest 20\% & Above normal \\
\hline $9-10$ & The highest 20\% & Much above normal \\
\hline
\end{tabular}

\subsection{Low Flow Indices}

Another widely used approach for hydrological drought characterization is $\mathrm{Q}_{\mathrm{x}}$ obtained by threshold level method. It was developed by Yevejevich in 1983 (5). For drought indices, the $\mathbf{Q}_{\mathbf{7 0}}$ and $\mathbf{Q}_{\mathbf{9 0}}$ are commonly used. In fact, $\mathbf{Q}_{\mathbf{X}}$ is the discharge in flow duration curve that in x percent of the time, other discharges are greater than it. Among other low flow indices, it may be referred to $\mathrm{Q}_{7,10}$ that is a flow with 7-day moving average and 10-year recurrent period. In order to obtain this index, the 7-day moving average of daily discharges is calculated and then the minimum value is determined. Once this value is determined for each year, $\mathrm{Q}_{7,10}$ is regarded as a 10-year recurrent period of these values. $\mathrm{Q}_{7,20}$ and $\mathrm{Q}_{30,10}$ are interpreted in this way too [71-84].

\subsection{Atmospheric - Oceanic Oscillations Indices}

Atmospheric - oceanic oscillations involve interactions between atmosphere and ocean. In recent years, the scientific communities have found out that oceanic oscillations affect the precipitation in different parts of the world. As such, any small changes in temperature of ocean and sea water results in significant changes in atmospheric circulation and consequently the climatic conditions of the earth planet. Therefore, these fluctuations could be exploited to predict the precipitation and drought. Here, some of the most important indices in this category are introduced [85-112].

\subsection{Southern Oscillations Index (SOI)}

SOI represents pressure gradient between western and eastern Pacific. This index reflects atmospheric characteristics of Enso phenomenon and generally is obtained seasonally and monthly by difference in surface air pressure between Tahiti and Darwin. Tahiti $\left(12^{\circ} \mathrm{S}, 151^{\circ} \mathrm{W}\right)$ is located on central regions of Pacific Ocean and Darwin $\left(12^{\circ} \mathrm{S}, 131^{\circ} \mathrm{E}\right)$ is located on north of Australia.

This index is calculated by [39]:

$$
\begin{aligned}
& S O I=10 \times \frac{\text { Pdiff }- \text { Pdiff }_{a v}}{S D(\text { Pdiff })} \\
& \text { Pdiff }=P_{\text {Tahiti }}-P_{\text {Darwin }}
\end{aligned}
$$

Where,

$\mathrm{P}_{\text {Tahiti }}$ and $\mathrm{P}_{\text {Darwin }}$ denote monthly average of surface air pressure in Tahiti and Darwin, respectively. According to equation 9-2, $\mathrm{P}_{\text {diff }}$ is the difference between monthly surface air pressure in Tahiti and Darwin. Pdiff ${ }_{\text {av }}$ and SD (Pdiff) represent the monthly mean and standard deviation of $\mathrm{P}_{\text {diff }}$ respectively. By applying the multiplier 10, SOI scores are transformed to integer.

North Atlantic Oscillations index (NOA)

To compute this index, the pressure in both Gibraltar and Reykjavik poles is standardized separately. The standardization of pressure values is performed as equation 10-2 [113-130].

$$
D=\frac{P_{i}-P_{a v}}{S D}
$$

Where,

D: standardized monthly pressure 
$\mathrm{P}_{\mathrm{i}: \text { monthly mean pressure }}$

$\mathrm{P}_{\mathrm{av}}$ long term average of monthly pressure in studied period

SD: standard deviation of monthly pressure in studied period

Then, NOA index is calculated by:

$$
N O A=D_{\text {Gibraltar }}-D_{\text {Reykjavik }}
$$

Where,

$D_{\text {Gibraltar }}$ and $D_{\text {Reykjavik }}$ represent standardized monthly pressure in Gibraltar and Reykjavik, respectively.

\section{CONCLUSION}

Harmful impacts of drought, a phenomenon resulted from both climate change and human activities have long been observed in all communities and inability of mankind in dealing with this disaster has been proved so far. During recent years, the arid and semiarid regions experienced four types of drought and the precipitation less than average record; it has led to irreparable damages particularly in agricultural sector. Hence, the drought monitoring using modern indices to predict the onset and termination of drought period, severity and other features is deemed necessary in order to develop the required measures to overcome the drought before its occurrence.

\section{REFERENCES}

[1] Alizade, A, 2004. ‘Applied hydrology principles’ Imam Reza University publication.

[2] Alley, W. M. 1984. The PalmerDrought Severity Index: Limitations and assumptions. J. Climate. Appl. Meteoral.23: 1100-1109.

[3] Bahlme, H. N. and D. A. Mooley. 1980. Large- scale Drought / floods and monsoon circulation. Mon. Wea. Rev 108: 1197-1211.

[4] Beersma,J .J., and Buishnd, T.A. 2007. Drought in the Netherlands - Regional frequency analysis versus time series simulation. Journal of Hydrology, 347:332-346.

[5] Byun, h. R. and D. A. Wilhite. 199. Objective quantificatiom of drought severity and duration, J. Climate 12: $2747-2756$

[6] Eslamian, S., Hassanzadeh, H., Abedi-Koupaei, J., and Gheysari, M. 2012. Application of L-moment for Regional Frequency Analysis of Mounthly Drought indexes. International Journal of Hydrological Engineering ASCE, 17(1): 32-42.

[7] Farajzade, M. Movahe Danesh, Ghaemi, 2001. 'Drought analysis in Iran using some statistical indices'. Journal of agriculture, 5,2: 15-31.

[8] Freidman, D. G. 1957. The Precipitation of Long-Continuing drought in south and south west texas, Occasional Papers in Meteoorol., No: 1, The Travelers Weather Research Center, Hartford, CT.

[9] Gibbs, W. J. and J. V. Maher. 1967. Rainfall deciles as drought indicators. Bureau of Meteoral.Bull.No. 48, Commonwealth of Australia Melbourne.

[10] Ghasemi, M, 2007. 'To determine hydrological and meteorological drought indices in Kharkhe basin' M.Sc. thesis. Faculty of Agriculture, Isfahan industrial university.

[11] Gommes, R. and F. Petrassi. 1994. Rainfall variability and drought in Sub-Saharan Africa since 1960. Agrometeoral. Ser. Working Paper No. 9, Food Agric. Organ., Rome, Italy.

[12] Hassanzadeh, H., Eslamian, S., Abedi-Koupaei, J., and Gheysari, M. 2011. Application of L-moment for evaluating drought indices of cumulative precipitation deficit (CPD) and maximum precipitation deficit (MPD) based on regional frequency analysis. International Journal of Hydrology Science and Technology, 1(1):88-104.

[13] Hassanzade, 2009. 'Characterization of some new drought indices and their regional frequency analysis using linear momentum', M.Sc thesis, Faculty of Agriculture, Isfahan industrial university.

[14] Hayes, M.J. Drought Indicces. 2006. Available from: http://drought.unl.edu/whatis/ Indicces/.htm

[15] Hayes, M. J., M. D. Svoboda, D. A. Wilhite and O. V. Vanyarkho. 1999. Monitoring the 1996 Drought using the standardized Precipitation index. Bull. Am. Meteoral . Soc. 80: 429-438

[16] Hidal, H. and Tallaksen, L.M. 2000. Drought event definition. Technical Report to the ARIDE Project No. 6

[17] Hollinyer, S. E., s. a. Isard and M. R. Welford. 1993. A new soil moisture drought index for predicting crop yields. In: Preprints 8th Conference on Applied Climatology, American Meteorological Society, Anaheim (CA), AMs, PP. 187-190 
[18] Hong,W.,G.,Kenneth and D.A.Wilhite. 2004. An agricultural drought risk-assesment model for corn and soybeans. International Journal of Climatology. 24(6):723-741.

[19] Ji, L. and Peters. A.J. 2003. Assessing vegetation response to drought in the northen Great Plains using vegetation and drought indices. Journal of Romote Sensing of Enviromental, 87:85-95

[20] Karl, T. R. and R.W. Knight. 1985. Atlas of Monthly Palmer Hydrological Drought Indices (1931-1983) for the Contiguous United States. Hist. Climatol Ser. 3-7, National Climate Data CenterT Asheville, North Carolina.

[21] Karimi, V; Kamkar Haghighi, A; Sepaskhah A; Khalili, D, 2001. 'hydrological droughts in Fars Province' Journal of agricultural sciences and natural resources. Volume 5, No.4. Isfahan industrial university, pp 112.

[22] Loukas A., Vasiliades L.N.R: Dalezios N.R. 2003. Intercomparison of meteorological drought indices for drought assessment and monitoring in Greece. Proceeding of the 8th International Conference on Environmental Science and Technology. Lemons Island and Greece.

[23] Loukas, A., Vasiliades, L., and Tzabiras, J. 2008. Climate Change Effects on Drought Severity, Advances in Geosciences, 17:23-29.

[24] Mainguet, M. 1999. Aridity, Drought and Human Development. Springer, Berlin

[25] Mavromatis, T. and J. W. Hensen. 2001. Interannual variability characteristics and simulated crop response of four stochastic weather generators. Agric. For. Meteoral . 109: 283-296.

[26] Mckee, T.B., N. J. Doesken and J. Kleist. 1993. A crop specific drought index for corn. Part 1. Model development and validation. Agron. J. 85: 388-395

[27] Mishra, Ashok K., Singh Vijay P., 2010, A review of drought concept, Journal of Hydrology, 391:202216.

[28] Mohammadnia Gharaei, S; Javdani, S; Javanmard, V; Khazanedari, 2000. 'Investigating the indices to evaluate meteorological drought and feasibility study of applying Palmer drought index in Iran' 1st national conference on drought mitigation and water shortage' Kerman, Volume 1, pp 44-52.

[29] Neural Network Toolbox User s Guide, 8th. 2000. The MathWorks, Inc.

[30] Ntale, H. K. Gan. 2033. Drought indices and their application to east Africa. Int. J. Climatol. 23: 1-24

[31] Rao, A.R. and T.L. Voeller. 1997. Development and testing of drought indicators Water Resour. Manage., 11: $119-136$

[32] Raziei, T.,Daneshkar Arasteh, P., Akhtari, R., and Saghafian, B. 2007. Investigation of meteorological Droughts in the Sistan and Balouchestan Province, Using Standardized Precipitation Index and Markov Chain Model. Iran-Water Resour. Res. J., 3(1): 25-35.

[33] Rooy, M. and P. Van. 1965. A Rainfall Anomaly index independent of time and space. Notos 14: P43.

[34] Shafer, B. A. and L. E. Dezman. 1982. Development of a surface Water Supply Index (SWSI) to assess the severity of drought conditions in snowpack runoff areas. In: Proceedings of The Western Snow Conference, Colorado State University, Fort Collins, Colorado PP. 164-175.

[35] Smakhtin, V.U., Hughes, D.A, 2007 Automated estimation and analyses of meteorological drought characteristics from monthly rainfall data. Enviromental Modelling \&Software, 22(6):880-890

[36] Smakhtin, V.U., Hughes, D.A, 2004. Reviwe, Aoutomated Estimation and Analyses of Drought Indices in South Asia. IWMI Working Paper 83.

[37] Sun, H. and D. J. Furbish.1997. Annual precipitation and river discharge in Florida in response to Ei Nini and La Nina-sea surface temperature anomalies. J. Hydrol., 199: 74-87.

[38] Webster N. 1978. Webster's New Twentieth Century Dictionary. World Publ. Co. Inc, USA.

[39] Yazdani, M; Chavoshi, S; Shirani, K; Khodeghlim, 2006. 'Hydrological drought in Zayanderud watershed' 1st regional conference on optimum utilization of water resources in Karoon and Zayanderud basins, Shahrekord.

[40] Zare Abyane, h; Mahboubi, A, 2004. 'Investigating drought trend in Hamedan region based on drought statistical indices' journal of research and development. No 64. Pp 2-15.

[41] Ostad-Ali-Askari, K., Shayannejad, M. 2015, Study of sensitivity of Autumnal wheat to under irrigation in Shahrekord, Shahrekord City, Iran. International Journal of Agriculture and Crop Sciences, 8 (4), 602-605.

[42] Shayannejad, M., Akbari, N., Ostad-Ali-Askari, K. 2015, Study of modifications of the river physical specifications on muskingum coefficients, through employment of genetic algorithm. International Journal of Development Research, 5(3), 3782-3785.

[43] Ostad-Ali-Askari, K., Shayannejad, M. 2015, The Reviews of Einstein's Equation of Logarithmic Distribution Platform and the Process of Changes in the Speed Range of the Karkheh River, Khuzestan province, Iran. International Journal of Development Research, 5(3), 3786-3790. 
[44] Ostad-Ali-Askari, K., Shayannejad, M., Ghorbanizadee-Kharazi, H. 2015, Assessment of artificial neural network performance and exponential regression in prediction of effective rainfall, International Journal of Development Research, 5(3),3791-3794.

[45] Shayannejad, M. Akbari, N. and Ostad-Ali-Askari, K. 2015, Determination of the nonlinear Muskingum model coefficients using genetic algorithm and numerical solution of the continuity. Int. J. of Science: Basic and Applied Research, 21(1),1-14.

[46] Ostad-Ali-Askari, K., Shayannejad, M. 2015, The Study of Mixture Design for Foam Bitumen and the Polymeric and Oil Materials Function in Loose Soils Consolidation. Journal of Civil Engineering Research, 5(2), 39-44. DOI: 10.5923/j.jce.20150502.04

[47] Sayedipour, M., Ostad-Ali-Askari, K., Shayannejad, M. 2015, Recovery of Run off of the Sewage Refinery, a Factor for Balancing the Isfahan-Borkhar Plain Water Table in Drought Crisis Situation in Isfahan Province-Iran. American Journal of Environmental Engineering, 5(2): 43-46. DOI: 10.5923/j.ajee.20150502.02

[48] Ostad-Ali-Askari, K., Shayannejad, M. 2015, Developing an Optimal Design Model of Furrow Irrigation Based on the Minimum Cost and Maximum Irrigation Efficiency. International Bulletin of Water Resources \& Development, 3(2), 18-23.

[49] Ostad-Ali-Askari, K., Shayannejad, M. 2015, Presenting a Mathematical Model for Estimating the Deep Percolation Due to Irrigation. International Journal of Hydraulic Engineering, 4(1), 17-21. DOI: 10.5923/j.ijhe.20150401.03.

[50] Ostad-Ali-Askari, K., Shayannejad, M. 2015, Usage of rockfill dams in the HEC-RAS software for the purpose of controlling floods. American Journal of Fluid Dynamics, 5(1), 23-29. DOI: 10.5923/j.ajfd.20150501.03.

[51] Ostad-Ali- Askari, K., Shayannejad, M. 2015, The effect of heterogeneity due to inappropriate tillage on water advance and recession in furrow irrigation. Journal of Agricultural Science, 7(6), 127-136.

[52] Shayannejad, M., Ostad-Ali-Askari, K. 2015, Effects of magnetized municipal effluent on some chemical properties of soil in furrow irrigation. International Journal of Agriculture and Crop Sciences, 8(3), 482489.

[53] Ostad-Ali-Askari, K., Shayannejad, M. 2015, Optimal design of pressurized irrigation laterals installed on sloping land. International Journal of Agriculture and Crop Sciences, ISSN 2227-670X. 8(5), 792-797.

[54] Ostad-Ali-Askari K, Shayannejad M, Eslamian S, Navab-Pour B. 2016, Comparison of solution of SaintVenant equations by characteristics and finite difference methods for unsteady flow analyzing in open channel. International Journal of Hydrology Science and Technology, 6(3), 9-18.

[55] Ostad-Ali-Askari K, Shayannejad M, Eslamian S, et al. 2017, Deficit Irrigation: Optimization Models. Management of Drought and Water Scarcity. Handbook of Drought and Water Scarcity, Taylor \& Francis Publisher, USA. Vol. 3. $1^{\text {th }}$ Edition, pp: 373-389.

[56] Eskandari S, Hoodaji M, Tahmourespour A, Abdollahi A, Mohammadian-Baghi T, Eslamian S, Ostad-AliAskari K. 2017, Bioremediation of Polycyclic Aromatic Hydrocarbons by Bacillus Licheniformis ATHE9 and Bacillus Mojavensis ATHE13 as Newly Strains Isolated from Oil-Contaminated Soil. Journal of Geography, Environment and Earth Science International, 11(2): 1-11.

[57] Shayannejad M, Ostad-Ali-Askari K, Eslamian S, et al. 2017, Development of a new method for determination of infiltration coefficients in furrow irrigation with natural non-uniformity of slope. Sustain. Water Resour. Manag., 3(2): 163-169.

[58] Shojaei N, Shafaei-Bejestan M, Eslamian S, Marani-Barzani M, P. Singh V, Kazemi M, Ostad-Ali-Askari K. 2017, Assessment of Drainage Slope on the Manning Coarseness Coefficient in Mountain Area. International Journal of Constructive Research in Civil Engineering (IJCRCE), 3(1): 33-40.

[59] Bahmanpour H, Awhadi S, Enjili J, Eslamian S, Ostad-Ali-Askari K. 2017, Optimizing Absorbent Bentonite and Evaluation of Contaminants Removal from Petrochemical Industries Wastewater. International Journal of Constructive Research in Civil Engineering (IJCRCE), 3(2): 34-42.

[60] Shayannejad M, Eslamian S, Gandomkar A, Marani-Barzani M, Amoushahi-Khouzani M, Majidifar Z, Rajaei-Rizi F, Kazemi M, P. Singh V, Dehghan SH, Shirvani-Dastgerdi H.R, Norouzi H, Ostad-Ali-Askari K. 2017, A Proper Way to Install Trapezoidal Flumes for Measurements in Furrow Irrigation Systems. International Journal of Research Studies in Agricultural Sciences (IJRSAS), 3(7): 1-5.

[61] Dehghan Sh, Kamaneh S.A.A., Eslamian S, Gandomkar A, Marani-Barzani M, Amoushahi-Khouzani M, Singh V.P., Ostad-Ali-Askari K. 2017, Changes in Temperature and Precipitation with the Analysis of Geomorphic Basin Chaos in Shiraz, Iran. International Journal of Constructive Research in Civil Engineering (IJCRCE), 3(2): 50-57.

[62] Ostad-Ali-Askari K, Shayannejad M. 2016, FLOOD ROUTING IN RIVERS BY MUSKINGUM'S METHOD WITH NEW ADJUSTED COEFFICIENTS. International Water Technology Journal, IWTJ, 6(3): 189-194. 
[63] Ostad-Ali-Askari K, Shayannejad M, Ghorbanizadeh-Kharazi H. 2017, Artificial Neural Network for Modeling Nitrate Pollution of Groundwater in Marginal Area of Zayandeh-rood River, Isfahan, Iran. KSCE Journal of Civil Engineering, 21(1):134-140. Korean Society of Civil Engineers. DOI 10.1007/s12205-016-0572-8.

[64] Shayannejad M, Ostad-Ali-Askari K, Ramesh A, Singh V.P., Eslamian S. 2017, Wastewater and Magnetized Wastewater Effects on Soil Erosion in Furrow Irrigation. International Journal of Research Studies in Agricultural Sciences (IJRSAS), 3(8): 1-14. http://dx.doi.org/10.20431/2454-6224.0308001.

[65] Shayannejad M, Soltani-Toudeshki A.R, Arab M.A, Eslamian S, Amoushahi-Khouzani M, MaraniBarzani M, Ostad-Ali-Askari K. 2017, A Simple Method for Land Grading Computations and its Comparison with Genetic Algorithm (GA) Method. International Journal of Research Studies in Agricultural Sciences (IJRSAS), 3(8): 26-38.

[66] Mohieyimen P, Eslamian S, Ostad-Ali-Askari K, Soltani M. 2017, Climate Variability: Integration of Renewable Energy into Present and Future Energy Systems in Designing Residential Buildings. International journal of Rural Development, Environment and Health Research(IJREH), 1(2): 18-30.

[67] Shayannejad M, Ostad-Ali-Askari K, Eslamian S, et al. 2017, Flow Hydraulic Investigation of the Wastewater on the Soil and Magnetic Field Effects in This Field. International Journal of Constructive Research in Civil Engineering (IJCRCE), 3(3): 1-15.

[68] Shayannejad M, Eslamian S, Singh V.P., Ostad-Ali-Askari K, et al. 2017, Evaluation of Groundwater Quality for Industrial Using GIS in Mountainous Region of Isfahan Province, Koh-Payeh, Isfahan, Iran. International Journal of Constructive Research in Civil Engineering (IJCRCE), 3(3): 24-37.

[69] Eslamian S, P. Singh V, Ostad-Ali-Askari K, R. Dalezios N, Yihdego Y, et al. 2017, Assessment of Aridity Using Geographical Information System in Zayandeh-Roud Basin, Isfahan, Iran. International Journal of Mining Science (IJMS), 3(2): 49-61.

[70] Askari Z, Samadi-Boroujeni H, Fattahi-Nafchi R, Yousefi N, Eslamian S, Ostad-Ali-Askari K, P. Singh V, R. Dalezios N. 2017, Prediction Comparison of Flow Resistance in Channels with Rounded and Angular Coarse Rough Beds. American Research Journal of Civil And Structural, 3(1): 1-15.

[71] Ghane M, Alvankar S.R., Eslamian S, Amoushahi-Khouzani M, Gandomkar A, Zamani E, Marani-Barzani M, Kazemi M, Soltani M, Dehghan SH, P. Singh V, Ostad-Ali-Askari K, HaeriHamedani M, ShirvaniDastgerdi H.R., Zalaki-Badil N. 2017, Sensitivity Analysis of Runoff Model by SWAT to Meteorological Parameters: A Case Study of Kasillian Watershed, Mazandaran, Iran. International Journal of Research Studies in Agricultural Sciences (IJRSAS), 3(10): 1-20.

[72] Shayannejad M, Abedi M.S., Eslamian S, Ostad-Ali Askari K, Gandomkar A, Cheng A, et al. 2017, The Contribution of Artificial Charging in Optimal Exploitation of Water Resources, Isfahan, Iran. InternationalJournal of Mining Science (IJMS), 3(3): 9-20.

[73] Eslamian S, Ostad-Ali Askari K, et al. 2017, Guidelines to Optimal Design of Furrow Irrigation Based on Plants, Soil and Furrow Specifications. International Journal of Constructive Research in Civil Engineering (IJCRCE), 3(4): 20-39.

[74] Coles, N. A. and Eslamian, S., 2017, Definition of Drought, Ch. 1 in Handbook of Drought and Water Scarcity, Vol. 1: Principles of Drought and Water Scarcity, Ed. by Eslamian S. and Eslamian F., Francis and Taylor, CRC Press, USA, 1-12.

[75] Dalezios, N. R., Dunkel, Z., Eslamian, S., 2017, Meteorological Drought Indices: Definitions, Ch. 3 in Handbook of Drought and Water Scarcity, Vol. 1: Principles of Drought and Water Scarcity, Ed. by Eslamian S. and Eslamian F., Francis and Taylor, CRC Press, USA, 24-44.

[76] Goyal, M. K. Gupta, V., Eslamian, S., 2017, Hydrological Drought: Water Surface and Duration Curve Indices, Ch. 4 in Handbook of Drought and Water Scarcity, Vol. 1: Principles of Drought and Water Scarcity, Ed. by Eslamian S. and Eslamian F., Francis and Taylor, CRC Press, USA, 45-72.

[77] Dalezios, N. R., Gobin, A., Tarquis Alfonso, A. M., and Eslamian, S., 2017, Agricultural Drought Indices: Combining Crop, Climate, and Soil Factors, Ch. 5 in Handbook of Drought and Water Scarcity, Vol. 1: Principles of Drought and Water Scarcity, Ed. by Eslamian S. and Eslamian F., Francis and Taylor, CRC Press, USA, 73-90.

[78] TishehZan, P. and Eslamian, S., 2017, Agricultural Drought: Organizational Perspectives, Ch. 6 in Handbook of Drought and Water Scarcity, Vol. 1: Principles of Drought and Water Scarcity, Ed. by Eslamian S. and Eslamian F., Francis and Taylor, CRC Press, USA, 91-108.

[79] Bazrkar, M. H., Eslamian, S., 2017, Ocean Oscillation and Drought Indices: Application, Ch. 8 in Handbook of Drought and Water Scarcity, Vol. 1: Principles of Drought and Water Scarcity, Ed. by Eslamian S. and Eslamian F., Francis and Taylor, CRC Press, USA, 127-136.

[80] Basu, R., Singh, C. K., Eslamian, S., 2017, Cause and Occurrence of Drought, Ch. 9 in Handbook of Drought and Water Scarcity, Vol. 1: Principles of Drought and Water Scarcity, Ed. by Eslamian S. and Eslamian F., Francis and Taylor, CRC Press, USA, 137-148. 
[81] Bazrafshan, J., Hejabi, S., Eslamian, S., 2017, Drought Modeling Examples, Ch. 11 in Handbook of Drought and Water Scarcity, Vol. 1: Principles of Drought and Water Scarcity, Ed. by Eslamian S. and Eslamian F., Francis and Taylor, CRC Press, USA, 167-188.

[82] Jonathan Peter Cox, Sara Shaeri Karimi, Eslamian, S., 2017, Real-Time Drought Management, Ch. 13 in Handbook of Drought and Water Scarcity, Vol. 1: Principles of Drought and Water Scarcity, Ed. by Eslamian S. and Eslamian F., Francis and Taylor, CRC Press, USA, 209-216.

[83] Garg, V. and Eslamian, S., 2017, Monitoring, Assessment, and Forecasting of Drought Using Remote Sensing and the Geographical Information System. Ch. 14 in Handbook of Drought and Water Scarcity, Vol. 1: Principles of Drought and Water Scarcity, Ed. by Eslamian S. and Eslamian F., Francis and Taylor, CRC Press, USA, 217-252.

[84] Dalezios, N. R., Tarquis Alfonso, A. M., and Eslamian, S., 2017, Drought Assessment and Risk Analysis, Ch. 18 in Handbook of Drought and Water Scarcity, Vol. 1: Principles of Drought and Water Scarcity, Ed. by Eslamian S. and Eslamian F., Francis and Taylor, CRC Press, USA, 323-344.

[85] Eslamian, S. and F. Eslamian, 2017, Handbook of Drought and Water Scarcity, Vol. 1: Principles of Drought and Water Scarcity, Francis and Taylor, CRC Group, USA, 660 Pages.

[86] Eslamian, S. and F. Eslamian, 2017, Handbook of Drought and Water Scarcity, Vol. 2: Environmental Impacts and Analysis of Drought and Water Scarcity, Francis and Taylor, CRC Group, USA, 680 Pages.

[87] Eslamian, S. and F. Eslamian, 2017, Handbook of Drought and Water Scarcity, Vol. 3: Management of Drought and Water Scarcity, Francis and Taylor, CRC Group, USA, 645. Pages.

[88] Angelakis, A. N., Chiotis, E., Eslamian, S., Weingartner, H., 2017, Underground Aqueducts Handbook, Taylor and Francis Group, CRC Press, USA, 511 Pages.

[89] Zalewski, M., McClain, M. E., and Eslamian, S., 2016, New Challenges and Dimensions of Ecohydrology, Part II Ecohydrology and Hydrobiology, Special Issue, Volume 16, Issue 2, Pages 71-124, Elsevier.

[90] Zalewski, M., McClain, M. E., and Eslamian, S., 2016, New Challenges and Dimensions of Ecohydrology, Part I, Ecohydrology and Hydrobiology, Special Issue, Volume 16, Issue 1, Pages 1-70, Elsevier.

[91] Godarzi, A., Eslamian, S., Ostad-Ali-Askari, K., 2016, Water in Literature Aspects: Social and Cultural Aspects, Nashreshahr, 135 Pages.

[92] Eslamian, S., Ostad-Ali-Askari, K., Salehi, M., Agha-Esmaeli, M., Sadeghi, M., Navabpour, B., MohriEsfahani, E., Mousavi-Madani, M., Zad-Bagher-Seighalani, E., Sadri, A., Shirvani-Dastgerdi, H. R., 2016, Engineering Operations Research: Linear Planning, Optimization and Genetic Algorithm, Kankash, 126 Pages.

[93] Eslamian, S., Ostad-Ali-Askari, K., Shayannejad, M., Ghasemi-Zeniani, M., Marzi-Nohadani, M., Heidari, F., Mohri-Esfahani, E., Haeri-Hamadani, M., 2016., Groundwater Hydrodynamic, Horoufchin, 193 Pages.

[94] Ostad-Ali-Askari, K., Shayannejad, M., Eslamian, S., Jahangiri, A. A., Shabani, A. H., 2016, Environmental Hydraulics of Open Channel Flows, Kankash, 332 Pages.

[95] Eslamian, S. S. and R. Mirabbasi, 2017, Application of Statistical Methods in Water Sciences, Aeij Publishing, Tehran, Iran, Under Press.

[96] Eslamian, S, 2015, (ed.) Urban Water Reuse Handbook, Francis and Taylor, CRC Group, USA, 1141 Pages.

[97] Eslamian, S., 2014, (ed.) Handbook of Engineering Hydrology, Vol. 1: Fundamentals and Applications, Taylor and Francis, CRC Group, USA, 636 Pages.

[98] Eslamian, S., 2014, (ed.) Handbook of Engineering Hydrology, Vol. 2: Modeling, Climate Change and Variability, Taylor and Francis, CRC Group, USA, 646 Pages.

[99] Eslamian, S., 2014, (ed.) Handbook of Engineering Hydrology, Vol. 3: Environmental Hydrology and Water Management, Taylor and Francis, CRC Group, USA, 606 Pages.

[100]Eslamian, S. S., 2013, Groundwater and Surface Water Interaction (GSWI): 3: Unconvenntional Groundwater, International Journal of Water, Special Issue Volume, Indersciences, Vol. 7, No. 1/2, 1-141.

[101]Eslamian, S. S., 2011, Groundwater and Surface Water Interaction (GSWI): 2. Case Studies, International Journal of Water, Special Issue Volume, Indersciences, Vol. 6, No. 1, 1-136.

[102]Eslamian, S. S., and S. Tarkesh Esfahani, 2011, Water Reuse (Urban Waste Water Application), Arkan Danesh Publishing, Isfahan, Iran, 327 Pages.

[103]Sharifani, M. M. and S. S. Eslamian, 2010, Humid Region Fruit Trees, Aeij Publishing, Tehran, Iran.

[104]Eslamian, S. S., 2009, Basin Ecology and Environment (BEE), International Journal of Ecological Economic \& Statistics, Ed., Special Issue Volume, CESER, Vol. 13, No. W09, 1-99.

[105]Eslamian, S. S., 2009, Groundwater and Surface Water Interaction (GSWI): 1. Quality, International Journal of Water, Special Issue Volume, Indersciences, Vol. 5, No. 2, 81-204. 
[106]Eslamian, S. S., 2009, Wind Modeling and Frequency Analysis (WMFA), International Journal of Global Energy Issues, Special Issue Volume, Indersciences. Vol. 32, No. 3, 175-304.

[107]Eslamian, S. S., 2008, Stream Ecology and Low Flows (SELF), International Journal of Ecological Economic \& Statistics, Ed., Special Issue Volume, CESER, Vol. 12, No. F08, 1-97.

[108]Eslamian, S. S., Soltani S. and A. Zarei, 2005, Application of Statistical Methods in Environmental Sciences, Arkan Publishing, Isfahan, Iran, 408 p.

[109]Eslamian, S. S. and S. Soltani, 2002, Flood Frequency Analysis, Arkan Publishing, Isfahan, Iran, 332 p.

[110]Eslamian, S. S., 1995, Regional Flood Frequency Analysis Using a New Region of Influence Approach, Ph.D. Thesis, Univ. of New South Wales, School of Civil Engineering, Dept. of Water Engineering, Sydney, NSW, Australia, 1995, Supervised by: Professor David H. Pilgrim, 380 P.

[111]Coles, N. A. and Eslamian, S., 2017, Definition of Drought, Ch. 1 in Handbook of Drought and Water Scarcity, Vol. 1: Principles of Drought and Water Scarcity, Ed. by Eslamian S. and Eslamian F., Francis and Taylor, CRC Press, USA, 1-12.

[112]Amiri, M. J. and S. S. Eslamian, 2010, Investigation of climate change in Iran, Journal of Environmental Science and Technology, Vol. 3, No. 4, 208-216.

[113]Ghazavi, R., Vali, A. B. and S. S. Eslamian, 2010, Impact of flood spreading on infiltration rate and soil properties in an arid environment, Water Resources Management, Vol. 24, No. 11, 2781-2793.

[114]Rajabi, A., Sedghi, H., Eslamian, S. S. and H. Musavi, 2010, Comparison of Lars-WG and SDSM downscaling models in Kermanshah (Iran), Ecol. Env. \& Cons., Vol. 16, No. 4, 1-7.

[115]Rahnamai Zekavat, P., Ghasemizadeh, R., Eslamian, S. S. and S. Tarkesh Isfahani, 2010, Journal of Flood Engineering, Vol. 1, No. 2, 175-184.

[116]Chavoshi Borujeni, S., Sulaiman, W. N. A. and S. S. Eslamian, 2010, Regional Flood Frequency Analysis Using L-Moments for North Karoon Basin Iran, Journal of Flood Engineering, Vol. 1, No. 1, 67-76.

[117]Kloub, N., Matouq, M., Krishan, M., Eslamian, S. S. and M. Abdelhadi, 2010, Monitoring of Water Resources Degradation at Al-Azraq Oasis, Jordan Using Remote Sensing and GIS Techniques, International Journal of Global Warming, Vol. 2, No. 1, 1-16.

[118]Akhavan S., Abedi-Koupai, J, Mousavi, S, F., Afyuni, M., Eslamian, S. S. and K. C. Abbaspour, 2010, Application of SWAT model to investigate nitrate leaching in Hamadan-Bahar Watershed, Iran, Agriculture, Ecosystems and Environment, Vol. 139, 675-688.

[119]Eslamian, S. S., Abedi-Koupai, J., Amiri, M, J., and A. R. Gohari, 2009, Estimation of Daily Reference Evapotranspiration Using Support Vector Machines and Artificial Neural Networks in Greenhouse, Research Journal of Environmental Sciences, Vol. 3, No. 4, 439-447.

[120]Eslamian, S. S. and N. Lavaei, 2009, Modelling Nitrate Pollution of Groundwater using Artificial Neural Network and Genetic Algorithm in an Arid Zone, International Journal of Water, Special Issue on Groundwater and Surface Water Interaction (GSWI), Vol. 5, No. 2, 194-203.

[121]Eslamian, S. S. and M. J. Khordadi, 2009, Comparing Rainfall and Discharge Trends in Karkhe Basin, Iran, International Journal of Ecological Economics \& Statistics (IJEES), Vol. 15, No. F09, 114-122.

[122]Eslamian, S. S. and B. Nekoueineghad, 2009, A Review on Interaction of Groundwater and Surface Water, International Journal of Water, Special Issue on Groundwater and Surface Water Interaction (GSWI), Vol. 5, No. 2, 82-99.

[123]Eslamian, S. S. and N. Zamani, 2009, Innovations in Wind Modelling, International Journal of Global Energy Issues, Special Issue on Wind Modelling and Frequency Analysis (WMFA), Vol. 32, No. 3, 175190.

[124]Eslamian, S. S. and H. Hasanzadeh, 2009, Detecting and Evaluating Climate Change Effect on Frequency Analysis of Wind Speed in Iran, International Journal of Global Energy Issues, Special Issue on Wind Modelling and Frequency Analysis (WMFA). Vol. 32, No. 3, 295 - 304.

[125]Eslamian, S. S., 2009, Editorial: Frontiers in Ecology and Environment, International Journal of Ecological Economic \& Statistics, Special Issue on Basin Ecology and Environment (BEE), Vol. 13, No. W09, 1-6.

[126]Eslamian, S. S. and M. Biabanaki, 2009, Low Flow Regionalization Models, International Journal of Ecological Economic \& Statistics, Special Issue on Stream Ecology and Low Flows (SELF), Vol. 12, No. F08, 82-97.

[127]Eslamian, S. S., 2009, Editorial: An Ecologically Based Low Flow Review, International Journal of Ecological Economic \& Statistics, Special Issue on Stream Ecology and Low Flows (SELF), Vol. 12, No. F08, 1-6.

[128]Nosrati, K., Eslamian, S. S., Shahbazi, A., Malekian, A. and M. M. Saravi, 2009, Application of Daily Water Resources Assessment Model for Monitoring Water Resources Indices, International Journal of Ecological Economic \& Statistics, Special Issue on Basin Ecology and Environment (BEE), Vol. 13, No. W09, 88-99. 
[129]Abedi-Koupai, J., Amiri, M. J., and S. S. Eslamian, 2009, Comparison of Artificial Neural Network and Physically Based Models for Estimating of Reference Evapotranspiration in Greenhouse, Australian Journal of Basic and Applied Sciences, Vol. 3, No. 3, 2528-2535,

[130]Ebrahimizadeh, M. A., Amiri, M. J., Eslamian, S. S., Abedi-Koupai, J. and M. Khozaei, 2009, The Effects of Different Water Qualities and Irrigation Methods on Soil Chemical Properties, Research Journal of Environmental Sciences, Vol. 3, No. 4, 497-503.

Citation: Dr. Kaveh Ostad-Ali-Askari et.al. (2017) A Review of Drought Indices, International Journal of Constructive Research in Civil Engineering, 3(4), pp.48-66. DOI: http://dx.doi. org/10.20431/2454-8693.03 04005

Copyright: (C) 2017 Dr. Kaveh Ostad-Ali-Askari, This is an open-access article distributed under the terms of the Creative Commons Attribution License, which permits unrestricted use, distribution, and reproduction in any medium, provided the original author and source are credited. 